専門医症例報告

$$
\begin{gathered}
\text { コーヌステレスコープクラウンとインプラントを応用して } \\
\text { 咬合再構成を行った症例 } \\
\text { 杉浦 裕介 }
\end{gathered}
$$

\title{
Occlusal Reconstruction with Cone Crown Telescope Denture and Implant
}

\author{
Yusuke Sugiura
}

抄 録

症例の概要：患者は，咀嚼障害および審美障害を主訴とする 57 歳女性。不良補綴物および部分歯列欠損 による咬合崩壊と咬合高径の低下，咬合平面の乱れが認められた。患者との十分なインフォームドコンセ ントの後，咬合再構成を行った。本症例は，上顎にコーヌステレスコープクラウンを用いた義歯，下顎遊 離端欠損部にインプラントを用い,ブリッジと共に固定性補綴とし，7年間，良好な経過をした症例である。 考察：上顎はコーヌステレスコープクラウンを用いることにより，リジッドサポートによる二次固定効果 と咬合面のワンユニット化による咬合力の分散が期待できる。また，下顎はインプラントを用いることに より固定性補綴を可能にした。

結論：咬合が崩壊している患者に対して，コーヌステレスコープクラウンとインプラントを応用した咬合 再構成を行い，長期にわたり安定した口腔環境が得られた。

和文キーワード

咬合平面，咬合高径，咬合再構成，コーヌステレスコープクラウン，インプラント

\section{ABSTRACT}

Patient: A 57-year-old female complained of mastication disorders and dissatisfaction with dental esthetics. Occlusion collapse due to a defective prosthesis and partial anodontia, a decrease in occlusal vertical dimension, and unequal occlusal plane levels was diagnosis, Occlusal reconstruction was performed on the patient. The prosthesis was completed with a cone crown telescope in the maxilla and anchored with an implant in the mandible, and the patient had a good clinical prognosis for 7 years.

Discussion: A cone crown telescope denture in the maxilla is expected to impart a secondary immobilizing effect by providing rigid support and distribution of the occlusal force by integrating the occlusal plane into a single unit. Additionally, an implant in the mandible enables fixation of the prosthesis.

Conclusion: Oral reconstruction provided a long-term stable oral environment which applied with cone crown telescope and implant in a patient with occlusion collapse.

\section{Key words}

occlusal plane, occlusal vertical dimension, occlusal reconstruction, cone crown telescope denture, implant 


\section{I 。緒言}

部分歯列欠損症例に対し補経処置を行う場合，残存歯 数，欠損様式，支台歯の状態あるいは上下顎残存歯の対 向関係などの口腔内の条件を考慮しつつ患者の希望に 即した補綴法を選択し，メンテナンスを含めて長期に渉 る良好な予後を期待する。

今回，上顎にコーヌステレスコープクラウン応用の可 撤性義歯，下顎にインプラントを施術し咬合再構成を行 い 7 年経過した症例について報告する .

\section{II. 症例の概要}

患者： 57 歳, 女性（初診時）.

初診: 平成 10 年 12 月.

主訴：咀嚼および審美障害.

現病歴：数年前より臼歯部咀嚼能力の低下および前 歯部審美障害を自覚しており，平成 10 年 12 月 3 の 冠脱離に伴う審美障害にて来院した。

現症：不良補綴物および部分歯列欠損による咬合崩 壊と咬合高径の低下，咬合平面の乱れ，上顎部分床義 歯不適合による咀嚼障害および審美障害を認めた。

口腔内所見：上顎は 71|1257 欠損であり, 左上 3 に歯肉縁下カリエス，6|46 には高度な歯槽骨吸収を 認めた。また, 46 においては歯の傾斜・移動も認めた。

下顎は 76 欠損であり, $\overline{21 \mid 12}$ 部に高度な歯槽骨の 吸収を認めた。また, 11 に根尖病巣, 6 に根分岐部病 変を認めた。口腔清掃状態は比較的良好であった。

診断と治療方針：下顎 $\overline{21 \mid 126}$ は保存不可能と診断 した。

上顎 616 は口蓋根のみを抜去し煩側根を保存した. プロビジョナルレストレーションおよび治療用義歯を 用い咬合支持の回復，審美障害の改善をし，残存歯の 根菅治療，歯周治療を行った。最終補綴装置は，上顎 を可撤性義歯，下顎はインプラントを遊離端欠損部に 利用し，ブリッジと共に固定性補綴とした。

図 1, 2, 3 に初診時における口腔内の状況およびパノ ラマエックス線写真, デンタルエックス線写真を示す.

\section{III．治療内容と経過}

患者の要望として挙げられた項目は，咀嚼障害およ び審美障害の改善であった。この要望を満たすために は，現状の咬合高径および咬合平面では適切な補綴物 の装着が困難であるため，治療方法について説明し患

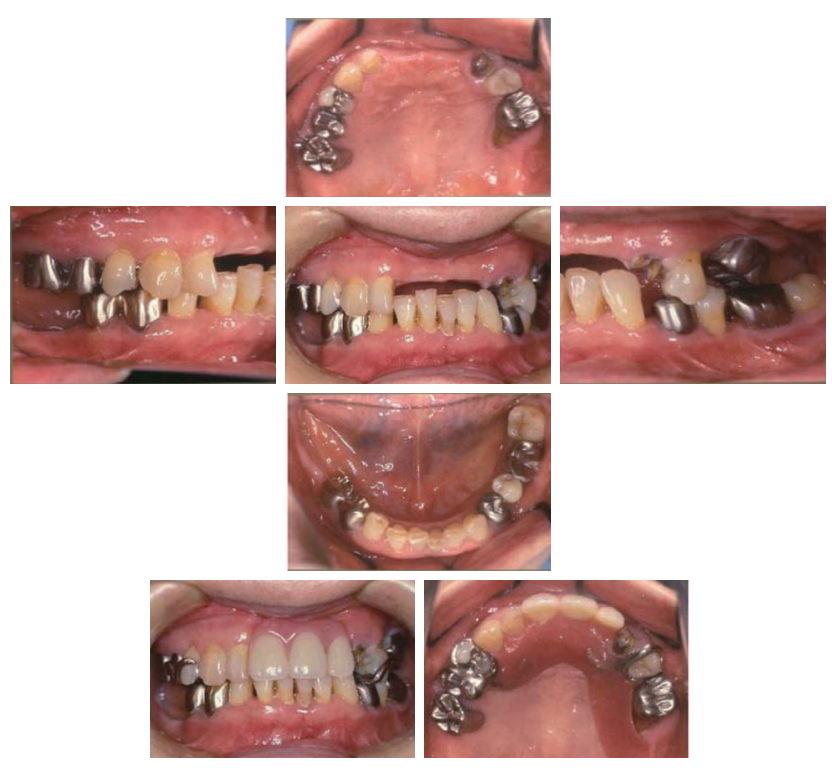

図 1 Oral cavity at first visit 初診時の口腔内

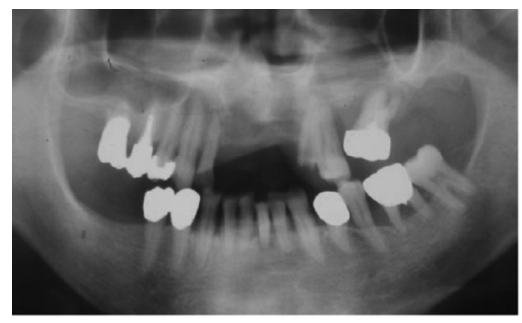

図 2 Panoramic radiography at first visit 初診時パノラマエックス線写真

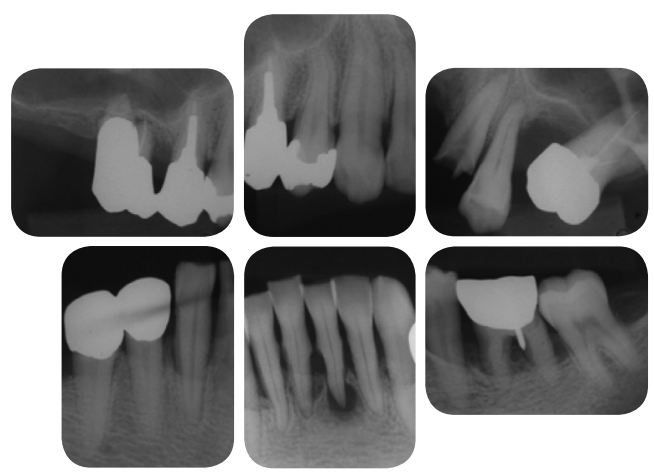

図 3 Dental radiography at first visit 初診時デンタルエックス線写真

者の理解と同意が得られたので，咬合再構成すること とした。

主訴である咀嚼および審美障害改善のため不良補綴 物を除去し，プロビジョナルレストレーションを装着 

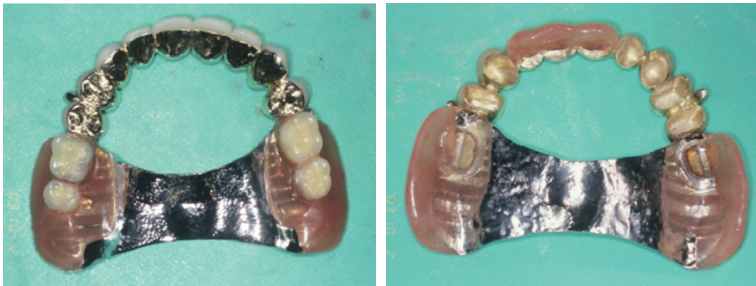

図 4 Completed Konus telescope denture 完成したコーヌステレスコープクラウン応用の可 撤性義歯
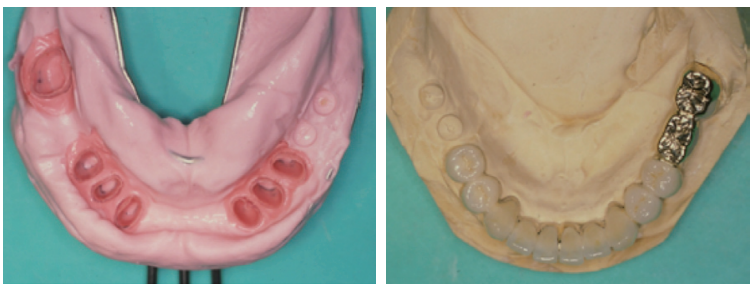

図 5 Final impression of mandible and completed bridge

下顎の精密印象および完成したブリッジ

し，欠損部分には治療用義歯を用い，14 歯対 14 歯の 咬合を確立し，安静空隙を指標とした咬合挙上，カン ペル平面を参考とした咬合平面の修正を行った。

上顎は $71 \mid 1257$ 欠損であり, 65432|346 残存してい たものの $\underline{6 \mid 6}$ の口蓋根は根尖付近まで，また，4 につ いては歯根 $3 / 4$ 程度の歯槽骨吸収が認められた。

上顎では残存歯すべてに根菅治療および歯周治療を 施し，平成 11 年 3 月， $\underline{6 \mid 6}$ は口蓋根の夕分割抜去し, 煩側根は根面板を装着した。

5432|34 を支台築造した後, 内冠を装着し平成 12 年 7 月，コーヌステレスコープクラウンを応用した可撤性 義歯を作製した（図4）.

下顎は 76 欠損であったが， $\overline{21 \mid 126}$ は高度な歯周疾 患により保存不可能と診断して平成 11 年 6 月抜歯処 置を行い, 残存歯は $\overline{543 \mid 3457}$ となった。平成 13 年 5 月に(5)(4)21|12 (3)(4)6 (7)ブリッジとし（図 5), 76損部に平成 12 年 10 月 $3 \mathrm{i}$ 社製インプラント (7 部： 直径 $4 \mathrm{~mm}$, 長さ $8.5 \mathrm{~mm}, 6$ 部：直径 $4 \mathrm{~mm}$, 長さ $10 \mathrm{~mm}$ ) を埋入し, 同部には，平成 13 年 6 月クラウ ンを作製して対応した，図 5,6,7 に治療終了時の口腔 内の状況およびパノラマエックス線写真, デンタルエッ クス線写真を示す (図 8).

また，治療終了時に咬合力測定システム Dental
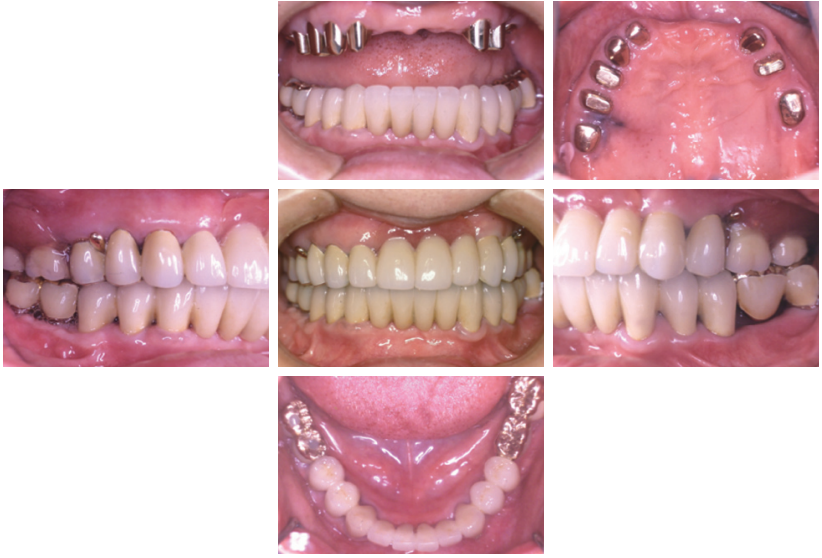

図 6

Oral cavity at completion of treatment 治療終了時の口腔内

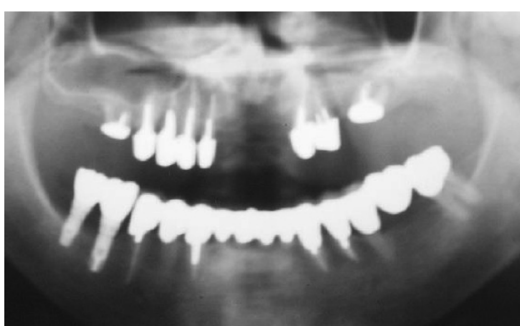

図 7 Panoramic radiography at completion of treatment 治療終了時のパノラマエックス線写真

Prescale/Occluzer FPD707 を用いて咬合力の確認を 行った.

リコールは約 $3 \sim 6$ カ月間隔で行い, その際には, 上顎では支台歯の過重負担および維持力の状態，義歯 の適合状態, 咬合接触状態の確認, 調整を行っている. また残存歯の歯周組織の状態も歯周組織検査とエック ス線診査を必要時に行っているが，良好な経過と思わ れる。

上顎義歯装着 6 年後の平成 18 年に一度リライニン グを行った。現在，治療終了後 7 年の経過（図 9）と なるが，わずかな調整により現在に至っており，患者 も満足している. 図 10 に現在のパノラマエックス線 写真を示す.

\section{IV. 考察}

咬合が崩壊している場合，プロビジョナルレストレー ションおよび治療用義歯を用いて咬合高径，咬合平面， 


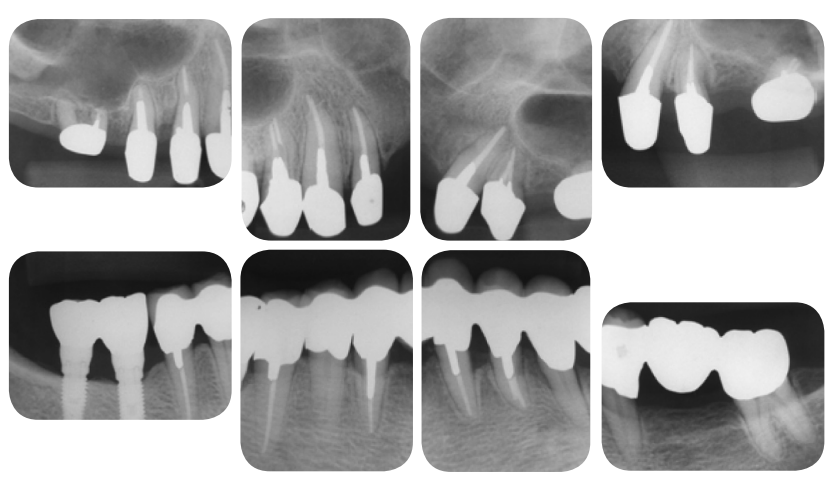

図 8 Dental radiography at the end of treatment 治療終了時のデンタルエックス線写真
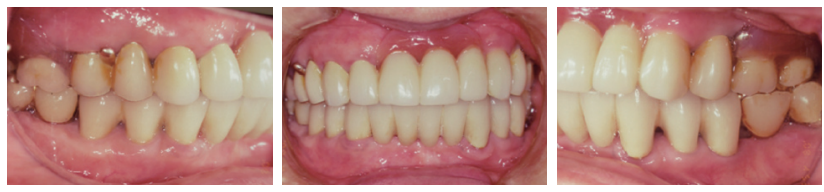

図 9

Oral cavity 7 years after treatment 術後 7 年経過時の口腔内

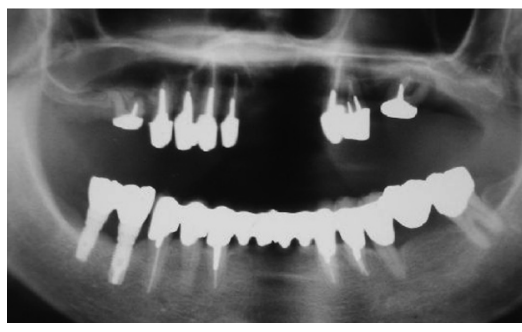

図 10 Panoramic radiography 7 years after treatment 術後 7 年経過時のパノラマエックス線写真

\section{V. 結 論}

咬合が崩壊している患者に対して，コーヌステレス コープ応用の可撤性義歯，および，インプラントを用 いて咬合再構成を行うことにより，長期に渉り安定し た咬合状態ならびに口腔環境が得られた。

\section{文献}

1）佐久間重光, 加藤賢吾, 山本一道, 荒木章純, 伊藤 裕. 咬合力分布による咬合の評価に関する研究 第 2 報. 愛院大歯誌 $1998 ； 36: 247-250$. た予後を獲得しやすいと考えられる。また今回，術後 7 年以上経過した時点で咬合力測定システムを用いて 計測を行った結果 $541 \mathrm{~N}$ を示した ${ }^{1)}$. 20 歳代女性の平 均咬合力は $824.8 \pm 342.9 \mathrm{~N}$ であることからすると, データ的にも満足の得られる状態であると推測される. エックス線診査でも安定した予後を経過している.

\author{
著者連絡先 : 杉浦 裕介 \\ 干 467-0038 名古屋市瑞穂区弥富町清水ヶ岡 72 \\ TEL : 052-861-7411 \\ FAX : 052-861-7413 \\ E-mail : sugiura-dc@rhythm.ocn.ne.jp
}

